\title{
PENGARUH KETERLIBATAN PEMAKAI DAN DUKUNGAN MANAJEMEN PUNCAK TERHADAP KINERJA SISTEM INFORMASI AKUNTANSI PADA BANK RAKYAT INDONESIA (PERSERO) TBK KANTOR CABANG TELUK BETUNG
}

\author{
Ritali Evi Mudrikah ${ }^{1}$, Muhammad Luthfi ${ }^{2}$ \\ ${ }^{1,2}$ Jurusan Akuntansi Universitas Malahayati \\ lutfi27@gmail.com
}

\begin{abstract}
ABSTRAK
Seiring dengan semakin berkembangnya Teknologi Informasi dalam kehidupan manusia, sehingga menuntut dunia perbankan untuk meningkatkan Teknologi Informasi yang digunakan. Bank Rakyat Indonesia (Persero) Tbk merupakan Badan Usaha Milik Negara (BUMN) yang meningkatkan penggunaan sistem informasinya dengan aplikasi sistem Core Banking System (CBS) Brinet (BRI Integrated Network and Information System), untuk dapat memberikan pelayanan yang baik atau kepuasan terhadap nasabahnya.

Penelitian ini bertujuan untuk memberikan bukti empiris faktor-faktor yang mempengaruhi kinerja sistem informasi akuntansi. Penelitian ini menggunakan data primer yang diperoleh dari kuesioner. Populasi dalam penelitian ini adalah pemakai sistem informasi akuntansi pada Bank Rakyat Indonesia (Persero) Tbk Kantor Cabang Teluk Betung di Bandar Lampung. Jumlah sampel yang diambil sebanyak 43 orang karyawan. Analisis data yang digunakan adalah analisis regresi linier berganda.

Hasil penelitian menunjukkan variabel keterlibatan pemakai dan dukungan manajemen puncak berpengaruh dan signifikan terhadap kinerja sistem informasi akuntansi.

Kata Kunci : Keterlibatan Pemakai Dalam Proses Pengembangan Sistem, Dukungan Manajemen Puncak, Kinerja Sistem Informasi Akuntansi
\end{abstract}

\section{LATAR BELAKANG}

Perbankan merupakan lembaga keuangan yang berfungsi sebagai penghimpun dana dari masyarakat dan menyalurkan dana kepada masyarakat. Oleh sebab itu, perbankan memerlukan sistem yang baik. Belakangan ini, semakin banyaknya transaksi yang beragam jenisnya menuntut kecermatan dan tepatnya penyajian data transaksi baik kepada pihak intern maupun pihak ekstern, sehingga diperlukan suatu sistem informasi termasuk sistem informasi akuntansi yang efektif dan tepat untuk memenuhi kebutuhan informasi.

PT Bank Rakyat Indonesia (Persero) Tbk. yang biasa disingkat BRI melakukan perubahan sistem desentralisasi menjadi sistem sentralisasi, dimana 
dalam sistem sentralisasi pihak tertinggi yaitu kantor pusat diberikan wewenang untuk mencatat segala transaksi yang terjadi di unit-unit kerja, sistem sentralisasi ini berfungsi untuk menghemat waktu dan biaya serta meminimalisir terjadinya risiko operasional, sistem sentralisasi melakukan pengembangan terhadap aplikasi sistem, aplikasi sistem core banking system OLSIB menjadi aplikasi sistem Core Banking System (CBS) Brinet (BRI Integrated Network and Information System), aplikasi sistem core banking system OLSIB merupakan aplikasi yang masih membutuhkan kurir untuk melakukan suatu pertukaran data dalam bentuk dokumen, wesel, kwitansi, dan lain-lain mengenai transaksi ataupun kegiatan lainnya, sehingga waktu yang dibutuhkan relatif lebih lama dan tidak dapat diprediksi. Sedangkan CBS Brinet merupakan aplikasi real time online yang menghubungkan kantor pusat dengan unit BRI yang tersebar diseluruh wilayah Indonesia dan luar negeri, Sehingga transaksi yang terjadi di unit-unit kerja langsung terlink kekantor pusat.

Pengembangan sistem informasi yang terus dilakukan BRI, merupakan hal yang penting dilakukan untuk mencapai suatu tujuan yaitu untuk menjadi modern bank (www.bri.co.id). Pengembangan sistem informasi yang terus dilakukan tidak lain terletak dari baik buruknya kinerja dari sistem tersebut. Sistem informasi akuntansi dalam sebuah organisasi merupakan salah satu hal yang perlu diperhatikan. Karena, baik buruknya kinerja dari sebuah sistem informasi akuntansi dapat dilihat melalui kepuasan pemakai sistem informasi akuntansi (user accounting information satisfaction) dan pemakaian sistem informasi akuntansi itu sendiri (user accounting information) Almilia dan Briliantien (2007).

Penelitian Amri (2009), mendapati adanya pengaruh keterlibatan pengguna, dukungan manajemen puncak, berpengaruh terhadap kinerja sistem informasi akuntansi.

\section{RUMUSAN MASALAH}

1. Apakah faktor keterlibatan pemakai berpengaruh terhadap kinerja sistem informasi akuntansi pada Bank Rakyat Indonesia (Persero) Tbk. Kantor Cabang Teluk Betung? 
2. Apakah dukungan manajemen puncak berpengaruh terhadap kinerja sistem informasi akuntansi pada Bank Rakyat Indonesia (Persero) Tbk. Kantor Cabang Teluk Betung?

\section{KERANGKA PEMIKIRAN}

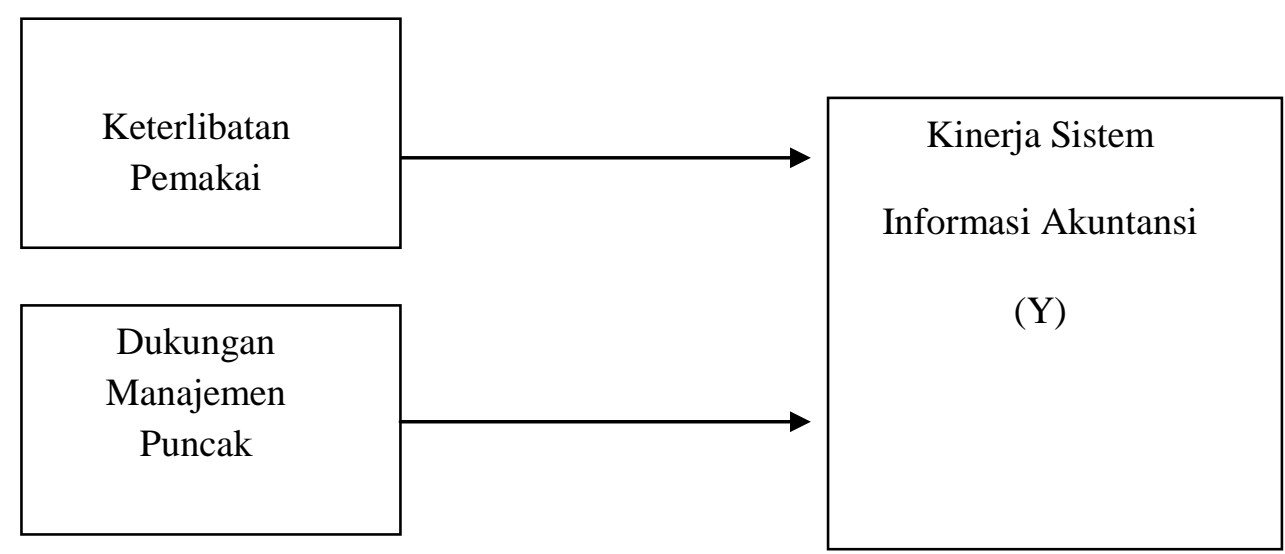

Gambar 1. Kerangka Pemikiran

\section{TUJUAN PENELITIAN}

Adapun tujuan penelitian ini adalah memberikan bukti empiris keterlibatan pemakai dan dukungan manajemen puncak dapat mempengaruhi keberhasilan kinerja sistem informasi akuntansi pada Bank Rakyat Indonesia (persero) Tbk. Kantor Cabang Teluk Betung.

\section{MANFAAT PENELITIAN}

Manfaat yang ingin dicapai dalam penelitian ini adalah:

\section{Bagi Perusahaan}

Penelitian ini diharapkan mampu memberikan tambahan informasi mengenai faktor-faktor yang mempengaruhi kinerja sistem informasi akuntansi, sehingga bisa menjadi masukan untuk meningkatkan kinerja perusahaan.

\section{Bagi Akademisi}

Penelitian ini diharapkan dapat memberikan informasi dan kontribusi serta menambah literatur tentang keterlibatan pemakai dan dukungan manajemen puncak berpengaruh terhadap kinerja sistem informasi akuntansi.

\section{Bagi Peneliti Selanjutnya}


Hasil penelitian ini dapat digunakan bagi peneliti lain sebagai acuan dan tambahan informasi untuk melakukan penelitian yang berkaitan dengan makalah ini dimasa yang akan datang.

\section{TELAAH LITELATUR DAN PENGEMBANGAN HIPOTESIS}

\section{Pengaruh keterlibatan pemakai dalam proses pengembangan sistem informasi terhadap kinerja SIA}

Menurut Terry dan Standing (2003) dalam Yohanna (2014), menyimpulkan bahwa keterlibatan pemakai merupakan keikutsertaan didalam proses pengembangan sistem yang diukur sebagai aktivitas yang telah dilakukan oleh para pemakainya.Tjhai Fung Jen (2002) dalam Almilia dan Briliantien (2007) berpendapat bahwa keterlibatan pemakai yang semakin sering akan meningkatkan kinerja SIA dikarenakan adanya hubungan positif antara keterlibatan pemakai dalam proses pengembangan sistem informasi dalam kinerja SIA. Untuk itu hipotesis dalam penelitian ini adalah:

$\mathrm{Ha}_{1}$ : Terdapat pengaruh antara keterlibatan pemakai dalam proses pengembangan sistem dengan kinerja sistem informasi akuntansi.

\section{Pengaruh dukungan manajemen puncak terhadap kinerja sistem informasi akuntansi}

Menurut Hasmi (2004) dalam Amri (2009), dukungan manajemen puncak merupakan pihak yang bertanggung jawab atas penyediaan pedoman umum bagi kegiatan sistem informasi. Tingkat dukungan yang diberikan oleh manajemen puncak bagi sistem informasi organisasi dapat menjadi suatu faktor yang sangat penting dalam menentukan keberhasilan semua kegiatan yang berkaitan dengan informasi. Tjhai Fung Jen (2002) dalam Almilia dan Briliantien (2007) berpendapat bahwa semakin besar dukungan yang diberikan manajemen puncak akan meningkatkan kinerja SIA, dikarenakan adanya hubungan yang positif antara dukungan manajemen puncak dalam proses pengembangan dan pengoperasian SIA dengan kinerja SIA. Untuk itu hipotesis dalam penelitian ini adalah:

$\mathrm{Ha}_{=2}$ : Terdapat pengaruh antara dukungan manajemen puncak dengan 


\section{METODE PENELITIAN}

\section{Populasi dan Sampel}

Populasi dalam penelitian ini diambil dari struktur organisasi yang terdapat diperusahaan, yaitu seluruh karyawan/staff berjumlah 83 orang. Teknik pengambilan sampel yang digunakan dalam penelitian ini adalah purposive sampling, yaitu pemilihan sampel dengan kriteria, karyawan yang dijadikan responden adalah karyawan yang terkait langsung dengan komputer, menggunakan sistem informasi akuntansi dalam menyelesaikan pekerjaannya dan, karyawan yang aktif (tidak cuti/pendidikan). Sehingga sampel yang diperoleh sebanyak 46 karyawan/staff.

\section{Metode Pengumpulan Data}

a. Studi Lapangan (Field Research)

Yaitu metode penelitian dengan melakukan pengamatan langsung pada perusahaan yang bersangkutan, melalui:

1) Observasi, menurut Sugiyono (2013) mengemukakan bahwa, observasi merupakan suatu proses yang kompleks, suatu proses yang tersusun dari berbagai proses biologis dan psikologis. Atau observasi yaitu dengan mengadakan pengamatan langsung pada saat peneliti menjalankan magang selama kurang lebih 2 bulan terhadap situasi dan kondisi sistem informasi yang digunakan oleh Bank Rakyat Indonesia (persero) Tbk. Kantor Cabang Teluk Betung.

2) Kuesioner, yaitu dengan membuat daftar pertanyaan, kemudian disebarkan kepada seluruh responden atau karyawan yang menggunakan sistem informasi akuntansi pada Bank Rakyat Indonesia (persero) Tbk. Kantor Cabang Teluk Betung.

\section{Hasil Uji Validitas}

Untuk menguji validitas instrumen penelitian dilakukan dengan menggunakan korelasi product moment, yaitu dengan cara mengkorelasikan tiap pernyataan dengan skor total. Kemudian, angka korelasi tersebut dibandingkan dengan angka kritis pada taraf signifikan 5\% dan pada baris $d f$ (degree of 
freedom) $\mathrm{n}-3$, yaitu 46-3=43 sehingga akan diperoleh nilai $\mathrm{r}$ tabel 0,301, atau apabila nilai korelasi hitung lebih besar dari angka kritis sebesar 0,301 maka pertanyaan dalam kuesioner dinyatakan signifikan/valid. Berdasarkan hasil perhitungan antara $\mathrm{r}$ hitung yang merupakan koefisien korelasi, dibandingkan dengan tingkat signifikasi setiap pertanyaan adalah dibawah 0,05 sehingga bisa diambil kesimpulan bahwa semua item pertanyaan adalah valid. Dengan demikian setiap item pertanyaan dalam kuesioner memiliki konsistensi internal dan dinyatakan valid.

\section{Hasil Uji Reliabilitas}

Tabel 1 Reliabilitas Instrumen Penelitian

\begin{tabular}{lllll}
\hline No & Variabel & Nilai $\alpha$ & Reliabilitas & Keterangan \\
\hline 1 & $\mathrm{X}_{1}$ & 0,633 & 0,600 & Reliabel \\
\hline 2 & $\mathrm{X}_{3}$ & 0,777 & 0,600 & Reliabel \\
\hline 3 & $\mathrm{Y}$ & 0,777 & 0,600 & Reliabel \\
\hline
\end{tabular}

Berdasarkan Tabel 1 terlihat bahwa semua nilai $\alpha$ lebih besar dari nilai angka kritis reliabilitas sebesar, sehingga semua butir pertanyaan dapat dipercaya dan dapat digunakan untuk penelitian selanjutnya.

\section{Uji Normalitas Data}

\section{Kolmogorov-Smirnov}

Tabel 2 Uji Normalitas Data dengan Kolmogorov-Smirnov

\begin{tabular}{|c|c|c|c|}
\hline Variabel & $\mathrm{K}-\mathrm{S} \mathrm{Z}^{*}$ & Signifikansi & Keterangan \\
\hline Keterlibatan Pemakai $\left(\mathrm{X}_{1}\right)$ & 0,757 & 0,616 & Distribusi Normal \\
\hline $\begin{array}{l}\text { Dukungan } \\
\text { Puncak }\left(X_{3}\right)\end{array}$ & 0,780 & 0,577 & Distribusi Normal \\
\hline $\begin{array}{l}\text { Kinerja Sistem Informasi } \\
\text { Akuntansi }\end{array}$ & 0,911 & 0,378 & Distribusi Normal \\
\hline
\end{tabular}

Keterangan: *K-S Z : Kolmogorov-Smirnov Test

Tabel 2 menunjukan bahwa variabel keterlibatan pemakai $\left(X_{1}\right)$, dukungan manajemen puncak $\left(\mathrm{X}_{2}\right)$, dan kinerja sistem informasi akuntansi $(\mathrm{Y})$ adalah 
berdistribusi normal. Tampak hasil dari perhitungan Kolmogorov-Smirnov Test sudah menunjukkan distribusi yang normal pada semua varibel (nilai signifikansi $>0,05)$.

2. Normal Probability Plot

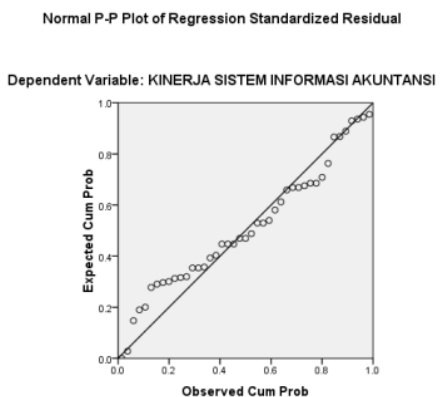

\section{Regresi Linier Berganda}

\section{Coefficients $^{\mathrm{a}}$}

\begin{tabular}{|c|c|c|c|c|c|c|}
\hline & & \multicolumn{2}{|c|}{$\begin{array}{l}\text { Unstandardized } \\
\text { Coefficients }\end{array}$} & \multirow{2}{*}{$\begin{array}{c}\begin{array}{c}\text { Standardized } \\
\text { Coefficients }\end{array} \\
\text { Beta }\end{array}$} & \multirow[b]{2}{*}{$\mathrm{t}$} & \multirow[b]{2}{*}{ Sig. } \\
\hline \multicolumn{2}{|c|}{ Model } & $B$ & Std. Error & & & \\
\hline 1 & (Constant) & 7.841 & 4.611 & & 1.700 & .097 \\
\hline & Keterlibatan Pemakai & .446 & .109 & .458 & 4.096 & .000 \\
\hline & $\begin{array}{l}\text { Dukungan Manajemen } \\
\text { Puncak }\end{array}$ & .910 & .224 & .453 & 4.052 & .000 \\
\hline
\end{tabular}

a. Dependent Variable: Kinerja Sistem Informasi Akuntansi

Berdasarkan koefisien regresi pada Tabel 4.12 maka persamaan regresi yang dapat dibentuk adalah:

$Y=7,841+0,446 X_{1}+0,910 X_{2}$

Arti dari persamaan diatas adalah:

$\alpha=7,841$ : konstanta bernilai 7,841 memberikan pengertian bahwa jika variabel keterlibatan pemakai, dukungan manajemen puncak konstan atau sama dengan nol (0), maka besarnya tingkat kinerja sistem informasi akuntansi sebesar 7,841.

$b_{1}=0,446$ : setiap peningkatan keterlibatan pemakai sebesar 1 satuan dan variabel lainnya konstan, maka kinerja sistem informasi akuntansi akan meningkat sebesar 0,446 satuan. 
$b_{2}=0,910$ : setiap peningkatan dukungan manajemen puncak sebesar 1 satuan dan variabel lainnya konstan, maka kinerja sistem informasi akuntansi akan meningkat sebesar 0,910 satuan.

\section{PEMBAHASAN}

Untuk mengetahui kuat dan lemahnya hubungan antara variabel (X) dengan variabel (Y) maka digunakan analisis R (koefisien korelasi). Dari hasil analisis dengan menggunakan bantuan program SPSS version 17.0 yaitu sebesar 0,758. Maka dapat disimpulkan bahwa terdapat hubungan yang cukup kuat antara variabel keterlibatan pemakai $\left(\mathrm{X}_{1}\right)$ dan dukungan manajemen puncak $\left(\mathrm{X}_{2}\right)$ dengan kinerja sistem informasi akuntansi (Y).

Dengan menggunakan bantuan program SPSS version 17.0 didapat hasil dari koefisien determinasi disesuaikan ( $R$ Square) 0,575 atau 57,5\%. Dari hasil tersebut maka dapat disimpulkan bahwa perubahan kinerja sistem informasi akuntansi pada Bank Rakyat Indonesia (Persero) Tbk Kantor Cabang Teluk Betung dipengaruhi oleh keterlibatan pemakai $\left(\mathrm{X}_{1}\right)$ dan dukungan manajemen puncak $\left(\mathrm{X}_{2}\right)$, sebesar 57,5\% sedangkan sisanya dipengaruhi oleh variabel lain.

Secara parsial dari hasil uji hipotesis ( $\mathrm{t}_{\text {hitung }}$ ) dan nilai Sig. Dapat dilihat dari tabel Coefficients ${ }^{a}$. Pembahasan hasil analisis data dapat dijelaskan dibawah ini :

\section{1) Keterlibatan pemakai}

Keterlibatan pemakai $\left(\mathrm{X}_{1}\right)$ memiliki tingkat signifikan (sig t) sebesar sebesar 0,000 kurang dari $\alpha(=0,05)$, dan nilai $t_{\text {hitung }} 4,096>t_{\text {tabel }} 1,685(d k=n-2)$. Berarti $\mathrm{H}_{\mathrm{a} 1}$ diterima dan $\mathrm{H}_{01}$ ditolak, dapat disimpulkan bahwa secara parsial variabel keterlibatan pemakai dalam proses pengembangan sistem berpengaruh signifikan terhadap kinerja sistem informasi akuntansi.

Keterlibatan pemakai berpengaruh terhadap kinerja sistem informasi akuntansi karena dalam kinerja sistem informasi akuntansi keterlibatan pemakai sangat berperan. Untuk itu dalam sistem informasi yang digunakan karyawan tidak boleh digunakan sembarangan oleh setiap karyawan karena berisikan informasi-informasi yang bisa bersifat rahasia dalam perusahaan. Oleh karena itu apabila karyawan mudah untuk menggunakan sistem dan terlibat semua tidak 
dapat meningkatkan kinerja sistem informasi akuntansi karena sistem informasi akan lebih mudah diketahui oleh karyawan yang tidak memiliki kepentingan.

Pemberian informasi seharusnya dilakukan oleh karyawan sesuai dengan deskripsi masing-masing pekerjaannya atau diberikan oleh pemakai yang benarbenar memiliki wewenang untuk mengakses informasi tersebut.

Hasil penelitian ini mendukung hasil penelitian yang dilakukan oleh Amri (2009), Darmawan, Yulita dan Ira (2011) dan Yohanna (2014). Amri (2009), Darmawan, Yulita dan Ira (2011) dan Yohanna (2014) sama-sama mendapati hasil bahwa variabel keterlibatan pemakai dalan proses pengembangan sistem informasi akuntansi memiliki pengaruh yang positif dan signifikan terhadap kinerja sistem informasi akuntansi. Hasil penelitian ini tidak mendukung hasil penelitian yang telah dilakukan oleh Dhiena (2011) dan Rizki (2012) yang mendapati hasil bahwa variabel keterlibatan pemakai dalam proses pengembangan sistem informasi akuntansi tidak.

\section{2) Dukungan manajemen puncak}

Dukungan manajemen puncak $\left(\mathrm{X}_{2}\right)$ memiliki tingkat signifikan (sig t) sebesar 0,000 lebih dari $\alpha(=0,05)$, dan nilai $t_{\text {hitung }} 4,052<t_{\text {tabel }} 1,685$. Dapat disimpulkan bahwa secara parsial variabel dukungan manajemen puncak berpengaruh signifikan terhadap kinerja sistem informasi akuntansi.

Hasi penelitian ini tidak mendukung penelitian Dhiena (2011), Darmawan, Yulita dan Ira (2011). Selain itu tidak mendukung teori yang dikemukakan oleh Sugiharto (2002) dalam Komara, (2005) yang menyatakan tingkat dukungan yang diberikan oleh top manajemen bagi sistem informasi organisasi bukan merupakan faktor penting dalam menentukan keberhasilan semua kegiatan yang berkaitan dengan sistem informasi.

Hasil penelitian ini mendukung hasil penelitian yang telah dilakukan oleh Amri (2009), Rizki (2012) dan Yohanna (2014) yang mendapati hasil bahwa dukungan manajemen puncak yang tinggi akan mengakibatkan kinerja sistem informasi akuntansi akan lebih tinggi. 


\section{KESIMPULAN}

Berdasarkan hasil penelitian dan pembahasan yang dilakukan terhadap keterlibatan pemakai, kemampuan teknik personal, dukungan manajemen puncak, program pelatihan dan pendidikan dan formalisasi pengembangan sistem informasi terhadap kinerja sistem informasi akuntansi pada Bank Rakyat Indonesia (Persero) Tbk Kantor Cabang Teluk Betung di Bandar Lampung, maka penulis mengambil kesimpulan:

1. Hasil uji secara parsial pengaruh antara variabel bebas dengan variabel terikat dapat disimpulkan sebagai berikut:

a. Hasil pengujian hipotesis pertama menunjukkan bahwa keterlibatan pemakai berpengaruh terhadap kinerja sistem informasi akuntansi. Hasil ini konsisten dengan penelitian yang dilakukan oleh Amri (2009), Darmawan, Yulita dan Ira (2011) dan Yohanna (2014) tetapi tidak konsisten dengan penelitian yang dilakukan oleh Dhiena (2011) dan Rizki (2012).

b. Hasil pengujian hipotesis kedua menunjukkan bahwa dukungan manajemen puncak berpengaruh terhadap kinerja sistem informasi akuntansi. Hasil ini konsisten dengan penelitian yang dilakukan oleh Amri (2009), Rizki (2012) dan Yohanna (2014), namun tidak konsisten dengan penelitian Dhiena (2011), Darmawan, Yulita dan Ira (2011), selain itu penelitian ini mendukung yang dikemukakan oleh Sugiharto (2002) dalam Komara (2005).

\section{SARAN}

Berdasarkan uraian diatas, maka dapat dikemukakan beberapa saran untuk peneliti selanjutnya:

1. Pokok pembahasan dalam penelitian ini adalah tentang kinerja sistem informasi akuntansi yang nampaknya tidak cukup dilakukan dengan satu kali pengamatan sebagaimana melalui pendekatan kuantitatif. Sehingga pada penelitian berikutnya diperlukan metode longitudinal untuk penelitian sejenis. 
2. Perlunya memperluas obyek penelitian, tidak hanya satu perusahaan saja sehingga lebih dapat dijadikan acuan bagi kepentingan generalisasi permasalahan, dan perlu menambah populasi penelitian agar data yang lebih kompleks dapat terbaca dengan mudah.

3. Perlu ditambah metode wawancara pada saat pengumpulan data untuk menghindari kemungkinan bias atau tidak obyektif dari responden dalam mengisi kuesioner.

4. Bagi Bank Rakyat Indonesia (Persero) Tbk Kantor Cabang Teluk Betung di Bandar Lampung dapat meningkatkan kinerja sistem informasi akuntansi dengan terus melakukan evaluasi dan pengembangan terhadap sistem sesuai dengan lingkungan intern perusahaan dan prosedur yang telah ditetapkan, sehingga dapat terus bersaing dalam lingkungan bisnis yang semakin kompetitif.

\section{DAFTAR PUSTAKA}

Almilia, Luciana Spica dan Irmaya Briliantien, Faktor-Faktor Yang Mempengaruhi Kinerja Sistem Informasi Akuntansi Pada Bank Umum Pemerintah di Wilayah Surabaya dan Sidoarjo. Jurnal STIE Perbanas Surabaya, http://www.info.stieperbanas.ac.id, 2007.

Amri, Faisal. 2009. Analisis faktor-Faktor yang Mempengaruhi Kinerja Sistem Informasi Akuntansi Studi Kasus pada PT. Coca Cola Bottling Indonesia. Fakultas Ekonomi Universitas Sumatera Utara.

Komara, Acep. 2005. Analisis Faktor-Faktor Yang Mempengaruhi Kinerja Sistem Informasi Akuntansi. Simposium nasional akuntansi 8. Solo.

Sugiyono. 2013. Metode Penelitian Bisnis, CV. Alfabeta, Jakarta.

www.bri.co.id

Yohanna, Yenny. 2014. Faktor-Faktor yang Mempengaruhi Kinerja Sistem Informasi Akuntansi pada Bank PANIN di Bandar Lampung. Fakultas Ekonomi Universitas Malahayati. 